Article

\title{
The Sustainable Strategy for Small and Medium Sized Enterprises: The Relationship between Mission Statements and Performance
}

\author{
Ethem Duygulu ${ }^{1}$, Emir Ozeren ${ }^{2}$, Pınar Işıldar ${ }^{2}$ and Andrea Appolloni ${ }^{3, *}$ \\ 1 Dokuz Eylul University, 35160 Buca, Izmir, Turkey; ethem.duygulu@deu.edu.tr \\ 2 Dokuz Eylul University, 35680 Foca, Izmir, Turkey; emir.ozeren@deu.edu.tr (E.O.); \\ pinar.isildar@deu.edu.tr (P.I.) \\ 3 University of Rome "Tor Vergata", 00133 Rome, Italy \\ * Correspondence: andrea.appolloni@uniroma2.it; Tel.: +39-333-1986-386 \\ Academic Editor: Giuseppe Ioppolo \\ Received: 7 March 2016; Accepted: 4 July 2016; Published: 21 July 2016
}

\begin{abstract}
The study aims to contribute to the literature by empirically examining the relationship between small and medium sized enterprises' (SMEs) mission statements and their performance in sustainable strategy formulation. Although it seems that there is a relatively vast amount of research with regard to mission statements of companies, very few studies have focused on the relationship between mission statements and performance. When these few studies are taken into consideration, it is difficult to reach any overall conclusion since their findings are mixed and inconclusive. To achieve this aim, 3034 SMEs operating in organized industrial zones in Turkey were examined via a survey approach. In order to investigate the relationships among the variables, nine categories of mission statements as independent variables and four performance indicators (financial, market, production, and overall) as dependent variables were analyzed through logistic regression. This study identified three mission components, (1) survival, growth, and profit; (2) philosophy and values; and (3) public image, as the common independent variables in explaining the performance of SMEs. Survival, growth, and profit is the most frequently observed mission component regardless of the subsector differentiation in the entire sample, which reflects the significance of business sustainability for SMEs in the Turkish manufacturing context. Besides, among all performance indicators, SMEs' market performance was found to be the lowest when compared to other performance indicators (financial, production, overall). Although the firms were placed in different manufacturing subsectors, similar mission statements were highlighted so that the discourse similarity might be considered as evidence of isomorphism characteristics for SMEs.
\end{abstract}

Keywords: mission statement; performance; sustainability; SMEs; strategy

\section{Introduction}

The important role of mission, vision, and strategy has been heavily emphasized in most of today's organizations in order to maintain a business sustainability performance in the long term. Although commonly used, these can be the least understood concepts. The discussions on the notion of mission can be observed in Peter Drucker's [1] study in 1973, which says "That business purpose and business mission are so rarely given adequate thought is perhaps the most important cause of business frustration and failure". Drucker's remark seems to be as true today as it was then. Due to main financial and economic constraints induced by the greatest economic crisis in recent decades, SMEs are increasingly compelled to develop strategies to increase their effectiveness and sustainability, in order to gain financial and performance goals [2]. According to Analou and Karami [3], developing a mission statement is considered to be a crucial factor in the formulation of sustainable business 
strategy in organizations. In the article by O'Gorman [4], the factors that determine the sustainability of growth in SMEs were explored and it was found that defining a strategic plan is an important element.

First, it might be beneficial to introduce the key terms examined in this study. The mission is the reason for the existence of the organization. The mission statement should answer these basic, yet essential questions: What is the organization's aim? Why does the organization exist? and What is the organization trying to accomplish? The mission statement is generally viewed as important to the long-term interests and survival of the firm [5] and the mission statement is a guide that is key to each company's strategy. The mission statement is capable of influencing the firm's performance, creating sustainable growth for the SMEs. Nevertheless, mission statements seem to receive superficial attention in most studies of organizational strategies and the strategic planning process [6]. Another related term, 'vision', is said to be the ideal state of the organization in the future. Miller and Dess [7] argue that vision "describes aspirations for the future" that inspire and appeal to the emotions and aspirations of the organization's members, whereas mission is defined to include such items as purpose, competitive distinctiveness, market definition, product/service definition, principal economic concerns, and values. It can be said that mission seems to be a part of strategic intent; however, it is not exactly the same thing as strategic intent. According to Hamel and Prahalad (cited in Bart and Baetz [8]), strategic intent refers to a particular point of view about the long-term market or competitive position that a firm hopes to build over the coming decade or so. Hence, the notion of strategic intent is intended to convey a sense of change, a new future direction, and a feeling of discovery and even profound destiny. Based on that view, "strategic intent" tends to come closer to the meaning of vision than "mission". The notion of vision is related to the establishment of certain long-term objectives that create a new competitive position for the firm in the long-term future; mission is much more concerned with identifying an organization's unique and enduring purpose, which is both rooted in the present and lasts for an indefinite period [8]. Strategy defines the direction to take towards an ideal state introduced in the vision. These tools are considered to be very useful in guiding the entire organization in the same direction [9].

While scholars and practitioners emphasize the significance of mission/vision statements, only a modicum of empirical research has been completed on mission/vision statements during the past 25 years and very few studies have considered mission statements in the context of a performance model, as Bart et al. argued [10]. Whereas there exist relatively more studies on mission/vision statements of large and global companies [11], a limited number of studies were found to have examined mission/vision statements in the context of strategy and performance from the viewpoint of SMEs. The current study tries to fill this void. In this regard, this article is specifically concerned with identifying the components that make up the mission and vision statements of Turkish SMEs and assessing the impact on their organizational performance within the SME context.

Considering the mixed, limited, and contradictory findings on the relationship between mission statements and performance discussed in the literature [12], a comprehensive and well-designed study is necessary to present empirically robust results in order to provide evidence in support of the positive (if any) relationship between mission statements and firm performance, and gain greater insights with regard to SMEs in terms of their strategy formulation. For this purpose, the research questions investigated in this study are as follows:

- What is the relationship (if any) between a firm's mission statements and performance within the SME context?

- What are the specific content characteristics of mission statements in Turkish SMEs and do firms have ideal mission components?

- What should the mission statements of SMEs include? Does the specific inclusion of any one particular mission component make a difference in terms of a firm's performance?

- Is it possible to have certain suggestions for SME managers in formulating sustainable business strategies based on the relationship between mission statements and performance? 


\section{Relevant Literature and Previous Research Evidence}

There is an overwhelming consensus in the literature that the development and management of business missions is fundamental for the survival and growth of any business [13]. However, there is a remarkable lack of empirical evidence for the acclaimed and assumed positive effects of mission statements [14]. In a similar vein, there is no evidence to suggest that mission statements create a difference in terms of an industrial firm's performance as Bart argued [6]. A few studies gave limited empirical support to the idea that mission statements are valuable and contribute to higher profits $[15,16]$. The prior studies prevailing in the literature that examine the impact of mission statements on firms' performance can be summarized under two headings. The first group of studies argue that there is no significant relationship to be found between a firm's mission statements and performance, whereas the second group of studies claim that there is a positive relationship between mission statements and a firm's performance.

David found no difference between the performance measures of 75 firms with formal mission statements and 106 firms that did not have any [17]. Similarly, Klemm et al. [18] found no statistically meaningful difference in the performance of firms, in terms of employee turnover or profits, when comparing firms with and without mission statements. Coats et al. also argued that low financial performance was just as likely as high financial performance to occur in firms that had a mission statement [19]. Wilson concluded that having a mission statement is no guarantee of success, nor does the lack of one guarantee failure [20]. Finally, research findings based on the work of O'Gorman and Doran demonstrated that mission statements per se are not correlated positively with SME performance and pointed out that expressing mission in a formal statement is certainly an option, but, at least for Irish SMEs, it is clearly not critical to success [21].

Despite the arguments against the positive relationship between mission statements and performance, there have been several attempts made at linking firm performance with the existence of a company mission statement. The research by Pearce and David was the first attempt to study empirically the relationship between mission statements and organizational performance. The authors examined the value of mission statements via content analysis to analyze the mission statements of high and low performing Fortune 500 companies [16]. Accordingly, the mission statements of high performing firms reflected more of the desired components (target consumers/markets, product/services, geographic domain, core technologies, survival, growth and profitability, company philosophy and self-concept, the firm's desired public image) than those of low performing Fortune 500 companies. In their pioneering work, Pearce and David [16] showed that the mission statements comprising more of the desired components led to enhanced performance.

Falsey [22] demonstrated that firms having mission statements that express a sense of responsibility to society have performed well over a sustained period of time. He concluded that businesses that had maintained their existence for at least one generation and had formulated formal principles explaining the company's philosophy had higher levels of performance. Collins and Porras [23] examined whether mission statements motivate employees and make a firm more competitive or not. Based on the responses obtained from U.S. executives to identify visionary companies, it was pointed out that these visionary firms perform better than other companies traded on U.S. stock exchanges. Rarick and Vitton [15] stated that there is a significant positive relationship between having a mission statement and shareholder equity. The average return on shareholder equity for firms with mission statements was $16.1 \%$ compared to $9.7 \%$ for those without mission statements. In Bart and Baetz's [8] study, which examines the relationship between mission statements and firm performance using a sample of 136 large Canadian organizations, it was found that mission statements and some of their specific characteristics are selectively associated with higher levels of organizational performance.

Even though in several studies it is argued that there is a link between a firm's mission statement and performance, there is actually little empirical evidence to prove this relationship. An important drawback of the mission literature is that there are limited empirical studies about the actual (as 
opposed to the perceived) effectiveness, overall usefulness, and performance relationship of mission statements. In this regard, this study aims to contribute to the existing literature by empirically examining the relationship between firms' mission statements and their performance in formulating the right strategy based on this link.

\section{Methodology}

The steps of the research conducted in this study are explained as follows: first, the sample characteristics, classification of mission and performance, and the measurement method are expressed in greater detail; second, the questionnaire design and definition of variables are presented; finally, the relationship among research variables is constructed.

\subsection{Sample and the Method of Data Analysis}

This study examined 3034 SMEs operating in organized industrial zones in Turkey. Data were obtained within the framework of an advanced joint research project of DEU (Dokuz Eylul University) and DPT (State Planning Organization) entitled "Performance Assessment of Organized Industrial Zones in Turkey and Strategy Formulation: Sub-regional Comparison" (Project number: 2003K120360). The population proportion of the firms grouped on a regional basis and selected by the random sampling method corresponds to $3.5 \%$ of the population. This proportion, seemingly minor, is approximately $20 \%$ if it is considered on a sub-region basis in every region. In the classification of businesses according to their size, the definition of the "Small and Medium Size Enterprise Development Agency of Turkey" (KOSGEB) was taken into account. The enterprises in the context of this research were incorporated in the analysis according to the NACE classification (shown in Appendix A) and sub-region definitions (shown in Appendix B).

Given the general characteristics of the sample, the majority of the respondents, i.e., 1487 of the entire sample, come from the city of Istanbul and the region of Marmara (the most developed region in Turkey). Secondly, 712 respondents are from the Western Anatolia region and the city of Ankara. The region that had the least participation in our sample is North East and Central Middle Anatolia with 52 respondents. Considering the education level of respondents in the sample, 23\% (697 respondents) hold an elementary school degree, 31.8\% (966 respondents) hold a high school degree, $41.2 \%$ (1251 respondents) hold a graduate degree, and 4\% (120 respondents) hold a postgraduate degree. When looking at the age level of respondents, $9.6 \%$ (273) are aged 25 and below, 34.9\% (1058) are between 26 and 35, 27.7\% (841) are between 36 and 45, 17.7\% (536) are between 46 and 55, and $10.1 \%$ (305) are 56 and above. In the analysis of data within the framework of this research, descriptive statistics, reliability and validity analysis (including exploratory factor analysis), $t$-test, and logistic regression analysis in order to explain causality relationship among variables were utilized by using version 16.0 of SPSS.

\subsection{Procedure}

Pearce and David [16] described the components of ideal mission statements as comprising eight elements: the specification of target consumers and markets; identification of principal products/services; specification of geographic domain; identification of core technologies; expression of commitment to survival, growth and profitability; specification of key elements in the company philosophy; identification of the company self-concept; and the identification of the firm's desired public image. David [24] extended the components of ideal mission statements proposed by Pearce and David by adding the element of employees. According to David's study, the following components were taken into consideration as being elements of ideal mission statements: customers (target market), products/services (offerings and value provided to customers), geographic markets (where the firm seeks customers), technology (the technology used to produce and market products), concern for survival/growth/profits (the firm's concern for financial soundness) philosophy (the firm's values, ethics, and beliefs), public image (contributions the firm makes to communities), employees (the 
importance of managers and employees), distinctive competence (how the firm is different from or better than competitors). These nine criteria suggested by David [24] were taken as the benchmark for this study.

The mission statements of SMEs investigated under the framework of this study were obtained via a semi-structured survey form. The respondents who were SME owners and managers were asked face to face to provide their company's mission statement. According to their responses, the mission statements were grouped into nine categories based on David's study [24], as shown in Table 1.

To assess the SMEs' performance in this study, multiple indicators were utilized concerning marketing, production, financial, and overall performance indicators. To measure the firm's performance, respondents (SME owners/managers) were asked to evaluate their last two years' performance on a five-point Likert scale. (1: Very low; 2: Low; 3: Steady; 4: High; 5: Very High). In this regard, a set of performance questions including 23 items was prepared in order to assess SME performance. These 23 items are as follows: sales; product returns; losses; customer satisfaction; shipments to ensure compliance; product assortment; number of customers; amount of output; export volume; business capital; total debt amount; production efficiency; effective usage of staff; number of exporting countries; capacity utilization rate; product costs; competitiveness; paid taxes; profit; dividends; the degree of employee morale, satisfaction, and commitment to the company goals; ease of finding available financial resources; and the degree to which last year's performance target was achieved.

Table 1. The classification of mission statements of participant SMEs.

\begin{tabular}{|c|c|}
\hline Categories & Sub-Categories \\
\hline $\begin{array}{c}\text { Customers } \\
\text { (target market) }\end{array}$ & $\begin{array}{l}\text { Developing our firm's scope } \\
\text { Extending the target customers (group) } \\
\text { Increasing the number of customers } \\
\text { Reaching and serving the large masses } \\
\text { Decreasing the interest in foreign markets } \\
\text { Gaining superiority over Chinese markets } \\
\text { Entering into a new area of customers }\end{array}$ \\
\hline Products/services & $\begin{array}{l}\text { Hygienic services } \\
\text { Steel importing } \\
\text { Offering new products to the market } \\
\text { Product development } \\
\text { Increasing production } \\
\text { Setting higher standards in manufacturing products } \\
\text { Being a service oriented company } \\
\text { Diversifying the products } \\
\text { Producing goods that respond to the needs of the market } \\
\text { Branding } \\
\text { Better service with low prices }\end{array}$ \\
\hline Geographic Markets & $\begin{array}{l}\text { Openness to foreign markets } \\
\text { Entering into international markets } \\
\text { Meeting the recent demands of the Turkish market alone } \\
\text { Doing joint business with EU countries } \\
\text { Making exports } \\
\text { Capturing the nearest and closest market }\end{array}$ \\
\hline Technology & $\begin{array}{l}\text { Achieving the monthly maximum production volume } \\
\text { Production to European standards } \\
\text { Leadership in technology } \\
\text { Increasing capacity } \\
\text { Transition towards mass production } \\
\text { Offering the latest technology to the customer } \\
\text { Transferring world technology to Turkey } \\
\text { Developing machine technology } \\
\text { Working with robot machines }\end{array}$ \\
\hline
\end{tabular}


Table 1. Cont.

\begin{tabular}{|c|c|}
\hline Categories & Sub-Categories \\
\hline $\begin{array}{l}\text { Survival, growth, } \\
\text { and profit }\end{array}$ & $\begin{array}{l}\text { Making money } \\
\text { Providing sustainability } \\
\text { Improving trade } \\
\text { Maintaining our capacity } \\
\text { Increasing the number of branches } \\
\text { Expanding the food sector } \\
\text { Making a profit } \\
\text { Increasing the market share } \\
\text { Growth and development } \\
\text { Providing capital to new factories } \\
\text { Becoming a limited liability company } \\
\text { Opening new branches } \\
\text { Economical prices } \\
\text { Achieving the predetermined target } \\
\text { Forging ahead in our sector } \\
\text { Transcending the energy problem by producing energy with the lowest cost } \\
\text { Making investments } \\
\text { Increasing competitiveness } \\
\text { Maintaining our current position in the market } \\
\text { Becoming a corporation } \\
\text { Advancing in the domestic market } \\
\text { Making future investment plans } \\
\text { Innovating our company } \\
\text { Advancing our company } \\
\text { Establishing factories }\end{array}$ \\
\hline Philosophy and values & $\begin{array}{l}\text { Increasing quality values } \\
\text { Being the best at all times } \\
\text { Contributing to the sectoral growth } \\
\text { Growing through quality } \\
\text { Being the best in our scope } \\
\text { Being innovative } \\
\text { Quality production }\end{array}$ \\
\hline Public (societal) image & $\begin{array}{l}\text { Contributing to the country growth } \\
\text { Being a reputable company in Turkey } \\
\text { Being a well-recognized firm } \\
\text { Becoming a worldwide company } \\
\text { Gaining recognition in the market } \\
\text { Having a good company status } \\
\text { Being a reliable company }\end{array}$ \\
\hline Employees & Employment \\
\hline Distinctive competence & $\begin{array}{l}\text { Being a pioneering firm } \\
\text { Shifting completely towards manufacturing } \\
\text { Specialized distributorship } \\
\text { Transforming our company to C.N.S. } \\
\text { Leading our sector } \\
\text { Being the biggest company in foreign markets } \\
\text { Quick service and good quality }\end{array}$ \\
\hline
\end{tabular}

In the light of factor analysis results, performance indicators were grouped under four categories: marketing, financial, production, and overall performance indicators. Table 2 shows the relevant performance indicators based on factor analysis results, and their corresponding mean score, Cronbach's alpha values and the total variance are explained. Based on the reliability analysis, the measurement scale employed in this study seems to be reliable considering the relatively high Cronbach's alpha values. KMO $(=0.832)$ and Bartlett test $($ Sig.: $0.000<0.05)$ results also show that the dataset is said to be appropriate for factor analysis. 
Table 2. The classification of relevant performance indicators.

\begin{tabular}{|c|c|c|c|c|}
\hline Categories & Sub-Categories & Mean & $\begin{array}{l}\text { Cronbach's } \\
\text { Alpha }\end{array}$ & $\begin{array}{l}\text { Total Variance } \\
\text { Explained }\end{array}$ \\
\hline $\begin{array}{l}\text { Marketing performance } \\
\text { indicators (MPIs) }\end{array}$ & $\begin{array}{c}\text { Sales } \\
\text { Export volume } \\
\text { Number of exporting countries }\end{array}$ & 2.9873 & 0.726 & 12.479 \\
\hline $\begin{array}{l}\text { Production performance } \\
\text { indicators (PPIs) }\end{array}$ & $\begin{array}{l}\text { Product returns } \\
\text { Losses }\end{array}$ & 3.7904 & 0.828 & 11.286 \\
\hline $\begin{array}{l}\text { Financial performance } \\
\text { indicators (FPIs) }\end{array}$ & $\begin{array}{c}\text { Business capital } \\
\text { Profit } \\
\text { Dividends } \\
\text { Ease with which to find } \\
\text { available financial resources }\end{array}$ & 3.2739 & 0.727 & 14.940 \\
\hline $\begin{array}{l}\text { Overall performance } \\
\text { indicators (OPIs) }\end{array}$ & $\begin{array}{c}\text { Customer satisfaction } \\
\text { Shipment to ensure compliance } \\
\text { Product assortment } \\
\text { Number of customers } \\
\text { Amount of output } \\
\text { Production efficiency } \\
\text { Effective usage of staff }\end{array}$ & 3.7630 & 0.821 & 21.061 \\
\hline
\end{tabular}

KMO Measure of Sampling Adequacy: 0.832 Approx. Chi-Square: 1.304E4 df: 120 Bartlett's Test of Sphericity Sig.: 0.000 .

\section{Findings}

The performance mean values of SMEs in terms of overall, financial, market, and production performance are summarized in Table 3 with respect to each mission component. When looking at the table overall, market performance mean scores were found to be the lowest compared to other performance indicators' mean values based on the five-point Likert scale. It can be seen that almost all market performance mean scores are below the moderate level, which is 3. (1: Very low; 2: Low; 3: Steady; 4: High; 5: Very High).

Table 3. The performance mean values of SMEs with respect to each mission statement.

\begin{tabular}{ccccc}
\hline & Overall Perf. & Financial Perf. & Market Perf. & Production Perf. \\
\hline Firms indicating no & 1417 & 1409 & 1277 & 1430 \\
mission statement & 3.7638 & 3.27777 & 2.9927 & 3.8245 \\
Mean & 23 & 23 & 22 & 23 \\
Customers & 3.6894 & 3.2609 & 2.5000 & 3.8043 \\
Mean & 159 & 161 & 141 & 161 \\
Products/services & 3.8257 & 3.2314 & 2.9835 & 3.7795 \\
Mean & 89 & 88 & 77 & 86 \\
Geographic Markets & 3.7881 & 3.2727 & 3.0693 & 3.6221 \\
Mean & 39 & 38 & 35 & 38 \\
Technology & 3.7033 & 3.3882 & 3.0000 & 3.6842 \\
Mean & 699 & 653 & 606 & 675 \\
Survival, growth, and profit & 3.7566 & 3.2814 & 2.9802 & 3.7415 \\
Mean & 147 & 148 & 138 & 155 \\
Philosophy and values & 3.8124 & 3.2601 & 3.1087 & 3.6742 \\
Mean & 157 & 155 & 130 & 154 \\
Public Image & 3.7279 & 3.2339 & 2.8872 & 3.9221 \\
Mean & 7 & 6 & 7 & 7 \\
Employees & 3.5918 & 3.0417 & 3.1429 & 3.8571 \\
Mean & 132 & 130 & 122 & 134 \\
Mean & 3.7219 & 3.2923 & 2.9645 & 3.8022 \\
\hline
\end{tabular}


Having analyzed the sample of this study, which comprises 3034 SMEs, as shown in Table 4, it can be concluded that firms overwhelmingly emphasize "sustainability, growth, and profit" as the most frequently used mission statement component. Namely, 709 SMEs out of the research sample underlined and used the "sustainability, growth, and profit" component in their mission statements. This finding is consistent with the literature since O'Gorman and Doran [21] also found that "concern for survival" is the most frequently used component in mission statements of Irish-owned SMEs. Another remarkable finding inferred from the analysis reveals that 1523 out of 3034 SMEs did not report any mission statement. Ironically, the overall performance of SMEs without any mission statement was found to be slightly higher than those with a mission statement. This finding is also consistent with the previous research evidence in the literature mentioned by Wilson [20] and Coats et al. [19]. The second most frequent mission component is public image with 170 SMEs, third is products and services with 169 SMEs, fourth is company philosophy and values with 162 firms, fifth is distinctive competence with 137 SMEs, sixth is geographical domain with 94 SMEs, seventh is technology with 39 SMEs, eighth is customers with 24 SMEs, and finally ninth is employees with eight SMEs. The mission components with regard to different sectors are shown in greater detail in Table 4. Considering the vision statements of the SMEs investigated within this study, it appears that the dominant vision statement is "growth in domestic markets", which is the most frequent vision item among all the SMEs. This seems to be wise for SMEs. Due to their limited size and resources, those firms set "growth in domestic markets" as their first priority. On the other hand, it should also be noted that 976 out of 3034 SMEs did not indicate any vision statement.

Based on the results of independent sample $t$-tests, as shown in Table 5, it can be said that SMEs' production performance shows a significant difference. This result should be carefully interpreted. Considering the significance (two-tailed) of the t-value (both are greater than 0.05), this result seems to be random for companies having a mission statement regarding customers. The SMEs' marketing performance does not show any significant difference, but the variance of companies having a mission statement regarding public image tends to be similar. These results led us to undertake further analysis of each mission statement and performance indicator.

Having conducted the logistic regression analysis, as shown in Table 6, the fifth (survival, growth, and profit), sixth (philosophy and values), and seventh (public image) mission components were found to be statistically significant at $0.03,0.02$, and 0.02 , respectively, in explaining production performance, while a causality relationship has not been found with regard to market performance. In this regard, these same three mission components, being the independent variables, were found to have a significant effect on production performance.

Considering the ODDS ratio $(\operatorname{Exp}(B))$ in Table $6, \beta$ (beta) coefficients for the independent variables were positive for the fifth (survival, growth, and profit) and sixth (philosophy and values) mission components so there was a positive association between these mission components and production performance, whereas the $\beta$ (beta) coefficient was negative for the seventh mission component (public image) so there was an inverse association between this mission component and production performance. As can be seen again from Table 6, the probability of being successful in production performance increased by 1227 times, compared to the probability of being unsuccessful in the fifth mission component, increased by 1453 times in the sixth mission component, but decreased by 0.657 times in the seventh mission component. There are two hypotheses about the validity of the model regarding the probabilistic assumptions in each mission component in relation to production performance:

$\mathrm{H}_{0}$ : the model is significant.

$\mathrm{H}_{1}$ : the model is not significant.

The hypotheses were tested via the Hosmer-Lemeshow Test; the chi-square value was found to be $0.000(p=1000>\alpha=0.05)$ and the $\mathrm{H}_{0}$ hypothesis was accepted. Considering the classification table of the model, its correct percentage (overall percentage) was found to be $59.5 \%$. 
Table 4. The frequency of mission statements based on NACE classification of SMEs.

\begin{tabular}{|c|c|c|c|c|c|c|c|c|c|c|}
\hline NACE & $\begin{array}{c}\text { 1st } \\
\text { Mission }\end{array}$ & $\begin{array}{c}\text { 2nd } \\
\text { Mission }\end{array}$ & $\begin{array}{c}\text { 3rd } \\
\text { Mission }\end{array}$ & $\begin{array}{c}\text { 4th } \\
\text { Mission }\end{array}$ & $\begin{array}{c}\text { 5th } \\
\text { Mission }\end{array}$ & $\begin{array}{c}\text { 6th } \\
\text { Mission }\end{array}$ & $\begin{array}{c}\text { 7th } \\
\text { Mission }\end{array}$ & $\begin{array}{c}\text { 8th } \\
\text { Mission }\end{array}$ & $\begin{array}{c}\text { 9th } \\
\text { Mission }\end{array}$ & $\begin{array}{l}\text { Missing } \\
\text { Items }\end{array}$ \\
\hline 15: manufacture of food and beverages (192 SMEs) & 2 & 13 & 8 & 1 & 50 & 18 & 4 & 1 & 10 & 85 \\
\hline 16: manufacture of tobacco products (1 SME) & & & & & & 1 & & & & \\
\hline 17: manufacture of textiles (373 SMEs) & 2 & 16 & 16 & 9 & 86 & 20 & 10 & 1 & 21 & 192 \\
\hline 18: manufacture of wearing and apparel and dyeing of fur (74 SMEs) & & 3 & 2 & 3 & 23 & 9 & 4 & & 3 & 27 \\
\hline $\begin{array}{l}\text { 19: tanning and dressing of leather; manufacturers of luggage, handbags, } \\
\text { saddlery, harnesses, and footwear ( } 80 \text { SMEs) }\end{array}$ & 1 & 5 & 6 & 1 & 23 & 10 & 3 & & 1 & 30 \\
\hline $\begin{array}{l}\text { 20: manufacture of wood and cork products, except furniture; manufacturers of } \\
\text { articles of straw and plaiting materials (57 SMEs) }\end{array}$ & & & 2 & & 14 & 2 & 1 & 1 & & 37 \\
\hline 21: manufacture of pulp, paper and paper products (50 SMEs) & & 2 & 2 & & 10 & 1 & 3 & & 1 & 31 \\
\hline 22: publishing, printing, and reproduction of recorded media (36 SMEs) & & 1 & 2 & & 14 & 2 & 1 & & 1 & 15 \\
\hline 23: manufacture of coke, refined petroleum products, and nuclear fuel (2 SMEs) & & & & & 2 & & & & & \\
\hline 24: manufacture of chemicals and chemical products (137 SMEs) & 2 & 11 & 7 & 4 & 24 & 7 & 8 & & 5 & 69 \\
\hline 25: manufacture of rubber and plastic products (260 SMEs) & 1 & 11 & 8 & 7 & 76 & 10 & 27 & 1 & 16 & 103 \\
\hline 26: manufacture of other non-metallic mineral products (104 SMEs) & 1 & 6 & & 2 & 23 & 4 & 5 & & 6 & 57 \\
\hline 27: manufacture of basic metals (317 SMEs) & 4 & 12 & 9 & 2 & 65 & 24 & 22 & & 11 & 168 \\
\hline $\begin{array}{l}\text { 28: manufacture of fabricated metal products, except machinery and equipment } \\
\text { (231 SMEs) }\end{array}$ & & 8 & 11 & & 64 & 6 & 12 & & 10 & 120 \\
\hline 29: manufacture of machinery and equipment (554 SMEs) & 5 & 42 & 10 & 5 & 120 & 27 & 34 & 2 & 24 & 285 \\
\hline 30: manufacture of office machinery and computers (4 SMEs) & & 1 & & & 1 & & & & & 2 \\
\hline 31: manufacture of electrical machinery and apparatus n.e.c. (101 SMEs) & & 2 & & 1 & 30 & 2 & 10 & & 6 & 50 \\
\hline $\begin{array}{l}\text { 32: manufacture of radio, television, and communication equipment and } \\
\text { apparatus (8 SMEs) }\end{array}$ & & & & & 2 & & & & & 6 \\
\hline $\begin{array}{l}\text { 33: manufacture of medical, precision, and optical instruments, watches and } \\
\text { clocks ( } 20 \text { SMEs) }\end{array}$ & 1 & & & & 6 & 1 & & & & 11 \\
\hline 34: manufacture of motor vehicles, trailers, and semi-trailers (110 SMEs) & 1 & 8 & 4 & 1 & 20 & 5 & 6 & 1 & 9 & 55 \\
\hline 35: manufacture of other transport equipment (4 SMEs) & & & & 1 & 1 & & & & & \\
\hline 36: manufacture of furniture, manufacturing n.e.c. (310 SMEs) & 3 & 26 & 9 & 2 & 54 & 13 & 20 & 1 & 12 & 170 \\
\hline 37 recycling (7 SMEs) & & & & & & & & & & 7 \\
\hline 72: computer and related activities (2 SMEs) & & & & & 1 & & & & & 1 \\
\hline
\end{tabular}


Table 5. Results of independent samples $t$-test.

\begin{tabular}{|c|c|c|c|c|c|c|c|c|}
\hline \multicolumn{5}{|c|}{ Levene's Test for Equality of Variances } & \multicolumn{4}{|c|}{$t$-Test for Equality of Means } \\
\hline & & $F$ & Sig. & $t$ & df & $\begin{array}{c}\text { Sig. } \\
\text { (2-tailed) }\end{array}$ & $\begin{array}{c}\text { Mean } \\
\text { Difference }\end{array}$ & $\begin{array}{l}\text { Std. Error } \\
\text { Difference }\end{array}$ \\
\hline \multirow{2}{*}{$\begin{array}{c}\text { Market } \\
\text { performance } \\
\text { public image }\end{array}$} & $\begin{array}{c}\text { Equal } \\
\text { variances } \\
\text { assumed }\end{array}$ & 0.309 & 0.578 & -2.342 & 2553 & 0.019 & -0.49158 & 0.20988 \\
\hline & $\begin{array}{c}\text { Equal } \\
\text { variance not } \\
\text { assumed }\end{array}$ & & & -2.498 & 21.418 & 0.021 & -0.49158 & 0.19682 \\
\hline \multirow{2}{*}{$\begin{array}{l}\text { Production } \\
\text { performance } \\
\text { customer }\end{array}$} & $\begin{array}{c}\text { Equal } \\
\text { variance } \\
\text { assumed }\end{array}$ & 6.148 & 0.013 & 1.603 & 2861 & 0.109 & 0.13913 & 0.08681 \\
\hline & $\begin{array}{c}\text { Equal } \\
\text { variance not } \\
\text { assumed }\end{array}$ & & & 1.737 & 174.490 & 0.084 & 0.13913 & 0.08011 \\
\hline
\end{tabular}

Table 6. The results of the logistic regression analysis in explaining production performance by mission statements.

\begin{tabular}{|c|c|c|c|c|c|c|c|c|c|}
\hline & & \multirow{2}{*}{ B } & \multirow{2}{*}{ S.E. } & \multirow{2}{*}{ Wald } & \multirow{2}{*}{ df } & \multirow{2}{*}{ Sig. } & \multirow{2}{*}{$\operatorname{Exp}(B)$} & \multicolumn{2}{|c|}{$95.0 \%$ C.I. for $\operatorname{Exp}(B)$} \\
\hline & & & & & & & & Lower & Upper \\
\hline \multirow{4}{*}{ Step $1^{\mathrm{a}}$} & @5th mission & 0.205 & 0.095 & 4.676 & 1 & 0.031 & 1.227 & 1.019 & 1.478 \\
\hline & @6th mission & 0.374 & 0.170 & 4.848 & 1 & 0.028 & 1.453 & 1.042 & 2.027 \\
\hline & @7th mission & -0.421 & 0.185 & 5.150 & 1 & 0.023 & 0.657 & 0.457 & 0.944 \\
\hline & Constant & -0.464 & 0.054 & 72.999 & 1 & 0.000 & 0.629 & & \\
\hline
\end{tabular}

In this study, in order to determine in which sectors production performance can be explained by the mission statements, logistic regression analysis was carried out and only the manufacture of food and beverages sector entered into the logistic regression model, as shown in Table 7. In this regard, the fifth (survival, growth, and profit) and sixth (philosophy and values) mission components as independent variables were found to have a significant effect on the production performance of the food and beverages sector. Considering the ODDS ratio $(\operatorname{Exp}(B)), \beta$ (beta) coefficients were positive for both these mission components so there was a positive association between them and production performance. The probability (likelihood) of being successful in the production performance of the food and beverages sector increased by 2074 times compared to the probability of being unsuccessful in the fifth mission component (survival, growth, and profit); and increased by 5616 times compared to the probability of being unsuccessful in the sixth mission component (philosophy and values).

Table 7. The results of the logistic regression analysis in explaining production performance by the relevant sectors.

\begin{tabular}{|c|c|c|c|c|c|c|c|c|}
\hline \multirow{2}{*}{ NACE } & \multirow{2}{*}{ B } & \multirow{2}{*}{ S.E. } & \multirow{2}{*}{ Wald } & \multirow{2}{*}{ df } & \multirow{2}{*}{ Sig. } & \multirow{2}{*}{$\operatorname{Exp}(B)$} & \multicolumn{2}{|c|}{$95.0 \%$ C.I. for $\operatorname{Exp}(B)$} \\
\hline & & & & & & & Lower & Upper \\
\hline 15: manufacturers of food & @5.mission 0.729 & 0.374 & 3.794 & 1 & 0.051 & 2.074 & 0.995 & 4.319 \\
\hline products and beverages & @6.mission 1.726 & 0.579 & 8.877 & 1 & 0.003 & 5.616 & 1.805 & 17.475 \\
\hline Step $1^{\text {a }}$ & Constant $\quad-0.770$ & 0.242 & 10.135 & 1 & 0.000 & 0.463 & & \\
\hline
\end{tabular}

a Variable(s) entered on step 1: @9.mission.

There are two hypotheses about the validity of the model regarding the probabilistic assumptions in each mission component in relation to production performance: 
$\mathrm{H}_{0}$ : the model is significant.

$\mathrm{H}_{1}$ : the model is not significant.

The hypotheses were tested via the Hosmer-Lemeshow Test; the chi-square value was found to be $0.000(p=1000>\alpha=0.05)$ and the $\mathrm{H}_{0}$ hypothesis was accepted. Considering the classification table of the model, its correct percentage (overall percentage) was found to be $64.5 \%$.

\section{Discussion}

Despite the fact that the literature identifies that an effective mission statement should include nine components, this study reveals three components-"survival, growth, and profit", "philosophy and values", and "public image" - as the main explanatory independent variables. The study puts forward these mission components as the common independent variables in explaining only production performance among the other performance indicators, which shows that SMEs in this study are predominantly production oriented. This fact is one of the main critical findings of our study and is also consistent with the literature. For instance, in a recent study by Babnik et al. [25] on mission statements' content dimensions among Slovenian organizations, similar orientations were revealed in line with the current study such as orientation towards stability, development and growth. Likewise, Sidhu examined the relationship between mission statement comprehensiveness and performance via regression analysis and found a significant positive effect of the former on the latter [26]. Yazhou and Jian also investigated the relationship between the mission statement and organizational performance within the context of Chinese nonprofit organizations [27]. These authors demonstrated that a mission statement has a positive relationship with the performance of nonprofit organizations and high-quality mission statements have significant effects on nonprofit performance. Recent studies have also been conducted to explore the relationship between mission statements and organizational performance in non-profit sector by taking into account the role of several variables in mediating (see Macedo et al. [2] for organizational commitment) or moderating (see Patel et al. [28] for affective commitment and Williams et al. [29] for top management commitment) that relationship. The findings of our study confirm the several results of recent studies in the literature $[2,28-30]$ by examining the relationship between mission statements and firm performance in Turkish manufacturing SME context. Accordingly, the presence of particular mission statement components in the studied firms was associated with enhanced production performance.

The underlying reason why firms in this study are mostly production oriented depends on their limited size and capacity, so that participant SMEs have a tendency to focus on internal organizational processes oriented in manufacturing rather than controlling and proactively responding to the external environment, which poses a threat for the survival and sustainability of SMEs in this context. This is also consistent with the research finding that SMEs' market performance is lower when compared to other performance indicators and even the mean score for market performance is below the moderate level. Inevitably, this fact emphasizes the necessity for further examination of SMEs from the viewpoint of market orientation with a specific focus on the causes and failures of low market orientation. The performance indicators, such as losses and product returns, may be regarded as the indicators of firms' production performance; thereby, within the cost leadership strategy, SMEs are shifting their focus towards production and attempting to minimize losses and product returns.

In this study, one of the findings that should be scrutinized closely is that 1523 out of 3034 SMEs did not indicate or report any mission statement. This situation can be better explained by the internalization of the mission argued by Marimon et al. [31]. Accordingly, defining a mission solely by the top management and unidirectional communication of this mission to employees does not ensure that employees well understood and internalized the mission of their companies. Having a mission and internalizing that mission are rather distinct concepts. As can be seen in the findings, more than one out of third participants in the sample of the current study do not know whether their companies have mission statements or not. Therefore, it can be claimed that the internalization of mission by 
employees should be viewed as one of the most critical objectives of a mission and is an essential condition for it to have an impact on the behavior and performance of a company [10,31,32].

Although the firms are placed in different manufacturing sub-sectors, the presence of similar mission statements can be regarded as their discourse similarity and can be interpreted as an evidence of isomorphism characteristics in line with institutional theory, which argues that institutional forces cause organizations to be similar to each other via coercive, normative, and mimetic pressures [33]. Two key points should be taken into consideration. Firstly, discourses tend to become similar due to the coercive pressure of the environment. The findings of our study are also consistent with Peyrefitte and David's [34] research that analyzes the mission statements of U.S. firms. Accordingly, firms might be subject to institutional pressures that influence what mission statements contain and also showed a comparable use of mission components across and within four industry environments in the way that selected firms respond to their stakeholders in similar ways. Secondly, SMEs that are incapable of influencing the external environment attempt to control internal organization variables via mimetic and normative regulations. For instance, firms are inclined to attain their sustainability through implementing imitation rather than fostering innovation in production processes. Indeed, Turkish SMEs inherently have innovation capability but ultimately this does not lead to innovation because Turkish SMEs have a tendency to imitate instead of innovate [35]. Thus, firms need to transform innovation potential into action. To achieve this, it can be suggested that SMEs should include innovation oriented statements in their missions since a recent research by Zhang et al. [36] demonstrates evidence that firms with innovation oriented mission have better innovation performance than firms without on a sample of the Chinese high-tech industry.

Since similar discourses may not create differences among the SMEs, in strategy formulation it is highly recommended for them to generate competitive advantage by adopting a "differentiation" and/or "focus" strategy considering their limited size, scope, and constrained resources. Firms might pursue focus strategy within a particular market niche, which involves concentrating on a narrow customer or product segment rather than competing against large firms in the mass markets [37]. In this sense, focus strategy might be considered as an appropriate strategy mechanism or tool for Turkish SMEs to maintain their survival, given the highly competitive market conditions.

When the mission component of "survival, growth, and profit" is considered, it may be regarded as the main goal of an enterprise in order to operate. The same behavior pattern can be observed in all organizations built upon economic foundations. "Philosophy and values" shows a positive and strong relationship with entrepreneurship behaviour and performance in terms of reflecting the management practices. Thereby, the fact that as an internal variable the "philosophy and values" component could have a mutual relationship with the "survival, growth, and profit" component, in terms of creating an entrepreneurship culture, should not be ignored. The successful performance of a firm is also related to its public image, mainly its reputation. It is a well-known fact that the recognition of a firm in society depends on a positive firm image; vice versa, a successful firm may create a positive public image.

The findings of this study are encouraging in the sense that the current research sheds some light on empirically explaining the link between mission statements and performance across various manufacturing industries located within the Turkish SME context. However, as with all research, this study inherently has several limitations. The mission statements of SMEs were obtained from SME managers and/or executives via self-reported questionnaires so that the mission statements relied heavily on self-expression of the key informants, which may have created bias. The mission statements were first classified and then analyzed based on the responses of the firms' key informants. However, it should also be noted that multiple measures were utilized to assess the SME performance rather than assuming a single criterion. Another key strength of the study stems from the fact that it is based on a relatively large sample size, unlike several studies (such as Sidhu [26]) reported in the literature. As a suggestion for further research, it is proposed that the mission and performance link should be examined by adopting objective measures of performance. A subjective measure was chosen in the current study since SMEs do not have a willingness to disclose their real performance data and 
sometimes the non-availability of real data is also evident in the SME context. Nevertheless, researchers such as Dess and Robinson [38] previously reported evidence of the convergent validity of subjective and objective performance measures.

\section{Conclusions}

This study contributes to our understanding of the impact of mission statements on performance of SMEs in sustainable business strategy formulation. Three mission components, (1) survival, growth, and profit; (2) philosophy and values; and (3) public image, appeared as common independent variables in explaining the performance of SMEs. "Survival, growth, and profit" is the most frequently observed mission component regardless of the subsector differentiation in the sample, which reflects the significance of sustainability for SMEs in the Turkish manufacturing context. Therefore, sustainable strategy formulation based on the relationship between SMEs' mission statements and performance should be clearly established in order to ensure common ground, provide certain direction and purpose, and share the common message with relevant and key stakeholders. This is actually in line with several research findings in the literature that show that a well-articulated mission statement offers critical insights to organizational stakeholders regarding the aims of the organization and can eventually lead to favorable sustainable outcomes that contribute to the entire firm [10,39-41]. Besides, among all performance indicators, SMEs' market performance was found to be the lowest when compared to other performance indicators (financial, production, overall). This research finding calls for further examination of SMEs from the viewpoint of market orientation with a specific focus on the causes and failures of low market orientation. Last but not least, participating firms were all engaged in the manufacturing industry but in different sub-sectors. Highlighting similar mission statements' components can be interpreted as an indication of isomorphism characteristics for SMEs in line with institutional theory, which forces organizations in the relevant field to be similar to each other via coercive, normative, and mimetic pressures.

Acknowledgments: The study was supported within the framework of an advanced research project of Dokuz Eylul University and Ministry of Development (formerly known as "State Planning Organization") of the Republic of Turkey entitled "Performance Assessment of Organized Industrial Zones in Turkey and Strategy Formulation: Sub-regional Comparison" (Project number: 2003K120360). We would like to thank the editor and the three anonymous reviewers for providing constructive comments and insightful suggestions which greatly improved this manuscript.

Author Contributions: Emir Ozeren is the main (principal) author of this research. Ethem Duygulu, Pınar Işıldar, and Andrea Appolloni shared joint responsibility and contributed equally to this work.

Conflicts of Interest: The authors declare no conflict of interest.

\section{Abbreviations}

The following abbreviations are used in this manuscript:

SMEs $\quad$ small and medium sized enterprises

NACE Nomenclature des Activités dans les Communautés Européennes

SPSS Statistical Package for Social Science

\section{Appendix A. NACE (Nomenclature des Activités dans les Communautés Européennes)}

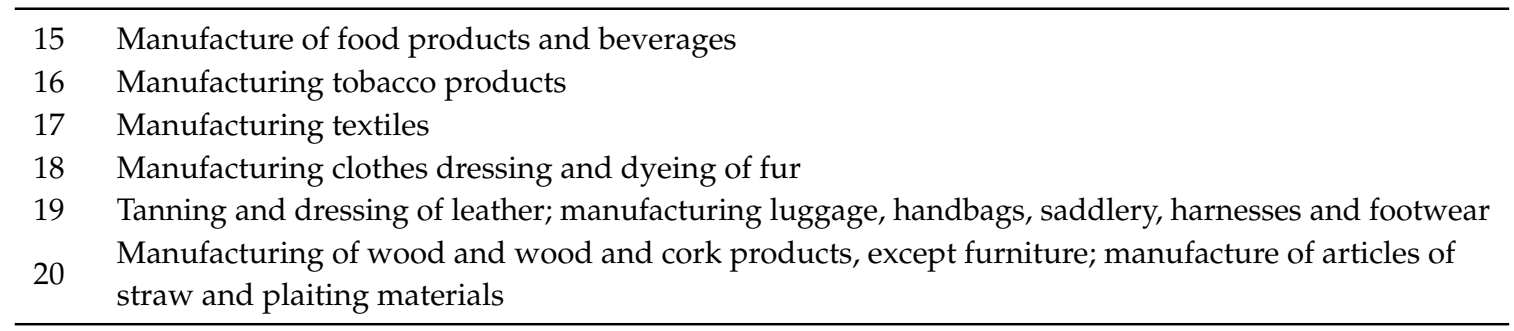




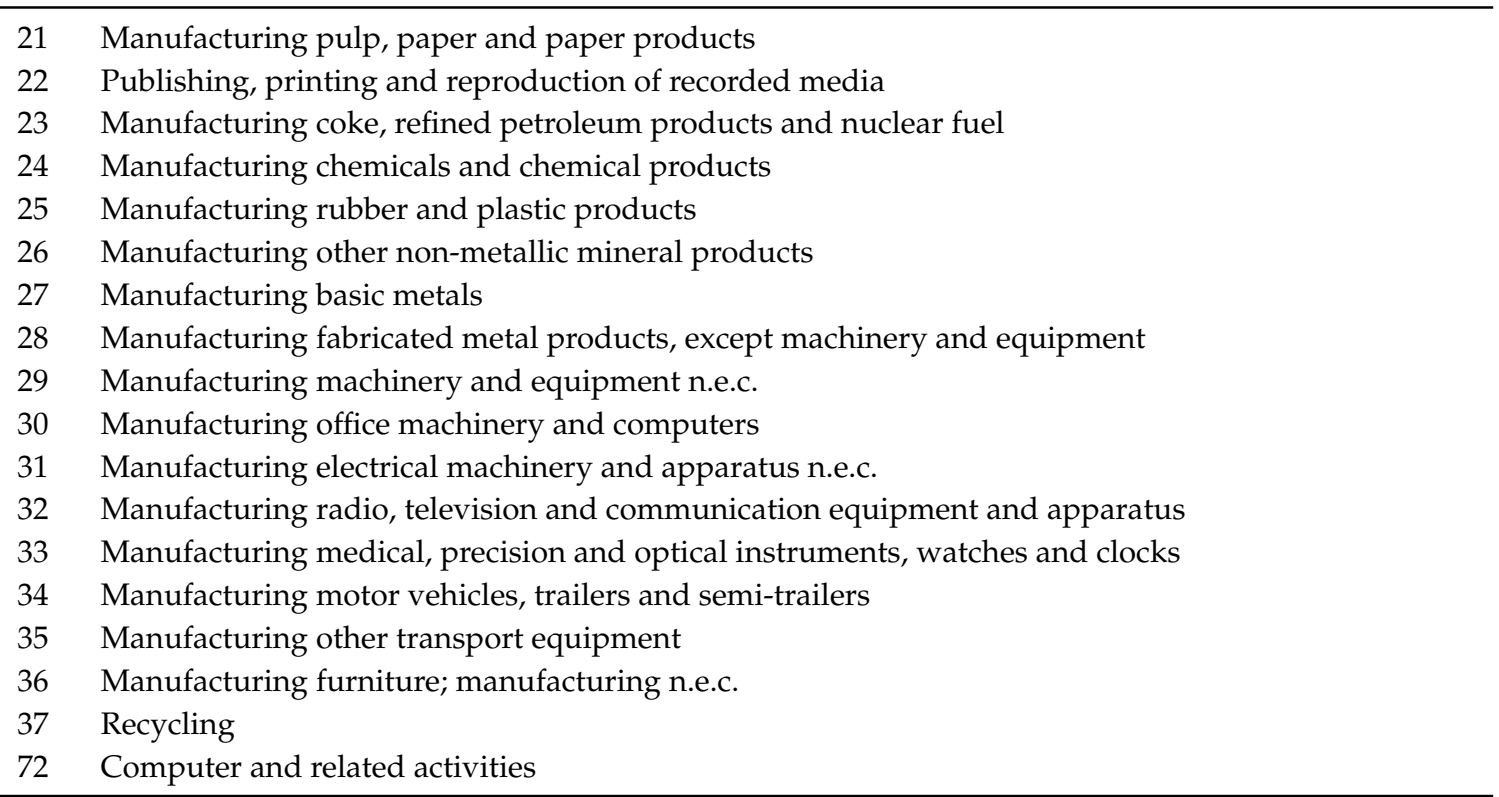

\section{Appendix B. Definition of Sub-Regions and Number of Firms Involved from Each Sub-Region}

\begin{tabular}{lll}
\hline TR1 & Subregion1 (İstanbul) & 1459 \\
TR2 & Subregion2 (Western Marmara) (Tekirdă̆, Edirne, Kırklareli, Balıkesir, Çanakkale) & 25 \\
TR3 & Subregion3 (Aegean) (İzmir, Aydın, Denizli, Muğla, Manisa, Afyon, Kütahya, Uşak) & 172 \\
& Subregion4 (Eastern Marmara) (Bursa, Eskişehir, Bilecik, Kocaeli, Sakarya, Düzce, & 186 \\
TR4 & Bolu, Yalova) & 712 \\
TR5 & Subregion5 (Western Anatolia) (Ankara, Konya, Karaman) & 114 \\
TR6 & Subregion6 (Mediterranean) (Antalya, Isparta, Burdur, Adana, Mersin, Hatay, \\
& Kahramanmaraş, Osmaniye) & 90 \\
TR7 & Subregion7 (Eastern Anatolia) (Kırıkkale, Aksaray, Niğde, Nevşehir,Kırşehir, Kayseri, \\
& Sivas, Yozgat) & 58 \\
TR8 & Subregion8 (Western Blacksea) (Zonguldak, Karabük, Bartın, Kastamonu, Çankırı, \\
TR9 & Sinop, Samsun, Tokat, Çorum, Amasya) & 18 \\
TR10 & Subregion9 (Eastern Blacksea) (Trabzon, Ordu, Giresun, Rize, Artvin, Gümüşhane) \\
TR11 & $\begin{array}{l}\text { Subregion11 (Central Anatolia) (Malatya, Elazlğ, Bingöl, Tunceli, Van, Muş, Bitlis, Hakkari) } \\
\text { TR12 }\end{array}$ & Subregion12 (Southeast Anatolia) (Gaziantep, Adıyaman, Kilis, Şanlıurfa, Diyarbakır, \\
& Mardin Batman, Şırnak, Siirt) \\
\hline
\end{tabular}

\section{References}

1. Drucker, P. Management: Tasks, Responsibilities, Practices; Harper \& Row: New York, NY, USA, 1973.

2. Macedo, I.M.; Pinho, J.C.; Silva, A.M. Revisiting the link between mission statements and organizational performance in the non-profit sector: The mediating effect of organizational commitment. Eur. Manag. J. 2016, 34, 36-46. [CrossRef]

3. Analoui, F.; Karami, A. CEOs and development of the meaningful mission statement. Corp. Gov. Int. J. Bus. Soc. 2002, 2, 13-20. [CrossRef]

4. O'Gorman, C. The sustainability of growth in small-and medium-sized enterprises. Int. J. Entrep. Behav. Res. 2001, 7, 60-75. [CrossRef]

5. Pearce, J.A. The company mission as a strategic tool. Sloan Manag. Rev. 1982, 15-24.

6. Bart, C.K. Industrial Firms and the Power of Mission. Ind. Mark. Manag. 1997, 26, 371-383. [CrossRef]

7. Miller, A.; Dess, G.G. Strategic Management, 2nd ed.; McGraw Hill: New York, NY, USA, 1996. 
8. Bart, C.K.; Baetz, M.C. The Relationship between Mission Statements and Firm Performance: An Exploratory Study. J. Manag. Stud. 1998, 35, 823-853. [CrossRef]

9. Naaranoja, M.; Haapalainen, P.; Lonka, H. Strategic Management Tools in Projects Case Construction Project. Int. J. Proj. Manag. 2007, 25, 659-665. [CrossRef]

10. Bart, C.K.; Bontis, N.; Taggar, S. A Model of the Impact of Mission Statements on Firm Performance. Manag. Decis. 2001, 39, 19-35. [CrossRef]

11. Bartkus, B.; Glassman, M.; McAfee, B. A Comparison of the Quality of European, Japanese and U.S. Mission Statements: A Content Analysis. Eur. Manag. J. 2004, 22, 393-401. [CrossRef]

12. Bartkus, B.; Glassman, M.; McAfee, B. Mission Statement Quality and Financial Performance. Eur. Manag. J. 2006, 24, 86-94. [CrossRef]

13. Levitt, T. Marketing Myopia. Harv. Bus. Rev. 1960, 38, 24-47. [CrossRef]

14. Piercy, R.; Morgan, N. Mission Analysis: An Operational Approach. J. Gen. Manag. 1994, 19, 1-19.

15. Rarick, C.; Vitton, J. Mission Statements Make Cents. J. Bus. Strateg. 1995, 16, 11-12. [CrossRef]

16. Pearce, J.; David, F. Corporate Mission Statements: The Bottom Line. Acad. Manag. Exec. 1987, 1, 61-82. [CrossRef]

17. David, F. How Companies Define Their Mission. Long Range Plan. 1989, 22, 90-97. [CrossRef]

18. Klemm, M.; Sanderson, S.; Luffman, G. Mission Statements: Selling Corporate Values to Employees. Long Range Plan. 1991, 23, 73-78. [CrossRef]

19. Coats, J.; Davis, E.; Longden, S.; Stacey, R.; Emmanuel, C. Objectives, missions and performance measures in multinationals. Eur. Manag. J. 1991, 9, 444-453. [CrossRef]

20. Wilson, I. Realizing the power of strategic vision. Long Range Plan. 1992, 25, 18-28. [CrossRef]

21. O'Gorman, C.; Doran, R. Mission Statements in Small and Medium-Sized Businesses. J. Small Bus. Manag. $1999,37,59-66$.

22. Falsey, T. Corporate Philosophies and Mission Statements; Quorum Books: New York, NY, USA, 1989.

23. Collins, J.; Porras, J. Organizational Vision and Visionary Organizations. Calif. Manag. Rev. 1991, 54, 30-52. [CrossRef]

24. David, F.R. It's time to redraft your mission statement. J. Bus. Strateg. 2003, 24, 11-14. [CrossRef]

25. Babnik, K.; Breznik, K.; Dermol, V.; Trunk Širca, N. The mission statement: organisational culture perspective. Ind. Manag. Data Syst. 2014, 114, 612-627. [CrossRef]

26. Sidhu, J. Mission Statements: Is it Time to Shelve Them? Eur. Manag. J. 2003, 21, 439-446. [CrossRef]

27. Yazhou, W.; Jian, L. Empirical Research on Influence of Mission Statements on the Performance of Nonprofit Organization. Procedia Environ. Sci. 2011, 11, 328-333. [CrossRef]

28. Patel, B.S.; Booker, L.D.; Ramos, H.M.; Bart, C. Mission statements and performance in non-profit organisations. Corp. Gov. 2015, 15, 759-774. [CrossRef]

29. Williams, R.I.; Morrell, D.L.; Mullane, J.V. Reinvigorating the mission statement through top management commitment. Manag. Decis. 2014, 52, 446-459. [CrossRef]

30. Alavi, M.T.; Karami, A. Managers of Small and Medium Enterprises: Mission Statement and Enhanced Organizational Performance. J. Manag. Dev. 2009, 28, 555-562.

31. Marimon, F.; Mas-Machuca, M.; Rey, C. Assessing the internalization of the mission. Ind. Manag. Data Syst. 2016, 116, 170-187. [CrossRef]

32. Wang, Y. Mission-driven organizations in Japan: Management philosophy and individual outcomes. J. Bus. Ethics 2011, 101, 111-126. [CrossRef]

33. DiMaggio, P.J.; Powell, W.W. The iron cage revisited: Institutional isomorphism and collective rationality in organizational fields. Am. Sociol. Rev. 1983, 48, 147-160. [CrossRef]

34. Peyrefitte, J.; David, F.R. A content analysis of the mission statements of United States firms in four industries. Int. J. Manag. 2006, 23, 296-301.

35. Duygulu, E.; Ozeren, E.; Bagiran, D.; Appolloni, A.; Muge, M. Gaining Insight into Innovation Culture in R \& D Centres: A Focus Group Study. Int. J. Entrep. Innov. Manag. 2015, 19, 117-146.

36. Zhang, H.; Garrett, T.; Liang, X. The effects of innovation-oriented mission statements on innovation performance and non-financial business performance. Asian J. Technol. Innov. 2015, 23, 157-171. [CrossRef]

37. Douglas, A.; Douglas, J.; Davies, J. Differentiation for competitive advantage in a small family business. J. Small Bus. Enterp. Dev. 2012, 17, 371-386. [CrossRef] 
38. Dess, G.G.; Robinson, R.B. Measuring organisational performance in the absence of objective measures: The case of the privately-held firm and conglomerate business unit. Strateg. Manag. J. 1984, 5, 265-273. [CrossRef]

39. Atrill, P.; Omran, M.; Pointon, J. Company mission statements and financial performance. Corp. Ownersh. Control 2005, 2, 28-35.

40. Desmidt, S.; Prinzie, A.; Decramer, A. Looking for the value of mission statements: A meta-analysis of 20 years of research. Manag. Decis. 2011, 49, 468-483. [CrossRef]

41. Donker, H.; Poff, D.; Zahir, S. Corporate values, codes of ethics, and firm performance: A look at the Canadian context. J. Bus. Ethnics 2008, 82, 527-537. [CrossRef]

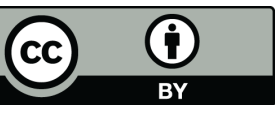

(C) 2016 by the authors; licensee MDPI, Basel, Switzerland. This article is an open access article distributed under the terms and conditions of the Creative Commons Attribution (CC-BY) license (http://creativecommons.org/licenses/by/4.0/). 